\title{
A Comprehensive Analysis of a Large Panel of Cancer/Testis (CT) Antigens in Korea Breast Cancer
}

Jae-Ho Bae ${ }^{\dagger}$, Min-Ju Kim', Hae-Rim Park, Myung-Ha Song, Jee-Yeon Kim, Chang-Hun Lee', Hi-Suk Kwak ${ }^{2}$ and Sang-Yull Lee*

Departments of Biochemistry, ${ }^{1}$ Pathology and ${ }^{2}$ Surgery, School of Medicine, Pusan National University, Ami-dong, Seo-gu, Busan, 602-739, Korea Received May 24, 2009 /Accepted June 9, 2009

\begin{abstract}
Cancer/testis (CT) antigens are immunogenic in cancer patients, exhibit highly tissue-restricted expression, and are considered promising target molecules for cancer vaccines. We investigated the expression of $13 \mathrm{CT}$ genes in 29 Korean patients with primary breast carcinoma. The most frequently expressed CT genes were MAGE-3 (66\%) and MAGE-1 (57\%), followed by LAGE-1 (55\%), NY-SAR-35 (49\%), MAGE-4 (41\%), NY-ESO-1 (38\%), CT-7 (24\%) and SSX-4 (24\%), whereas SSX-1, SSX-2, MAGE-10 and NY-TLU-57 were found to be expressed significantly less often (3-7\%) and SCP-1 not all. Expression of at least one antigen was observed in 28 breast cancer samples. Immunohistochemistry was performed for NY-ESO-1 and MAGE-3 protein expression in breast tumor samples. NY-ESO-1 and MAGE-3 proteins were expressed in 11 of 29 (38\%) and 12 of 29 (41\%) breast tumors. Our results suggest that CT antigens may be potential candidates for polyvalent immunotherapy in Korean breast cancer patients.
\end{abstract}

Key words : Breast cancer, cancer/testis (CT) antigen, cancer immunotherapy, NY-ESO-1, MAGE-3

Introduction

Breast cancer is one of the most common malignancies in women [3]. Although there are several established therapeutic methods for breast cancer; surgical resection, chemotherapy, and radiotherapy, a considerable proportion of patients with limited-stage disease develops metastatic disease. An attractive approach to reduce the rate of failures after primary treatment of breast cancer could be immunotherapeutic strategies, which should be most efficient in the state of minimal residual disease. In breast cancer, only few tumor antigens are known, and most are over-expressed in tumor cells but will also be found at a certain level in normal human cells, e.g., CEA, CA15-3, Her-2/neu, MUC-1 [10,14,16]. Expression of these genes in normal tissue limits their use as targets for specific immunotherapy.

Our current efforts to define molecular targets for cancer vaccines led to discovery of cancer/testis (CT) antigens, which are ideal for use in cancer immunotherapy, based on expression of a variety of human cancer but not in normal tissues except for testis [15]. To date, cancer/testis (CT) antigens, of which more than 40 have now been identified [13],

*Corresponding author

Tel : +82-51-510-8084, Fax : +82-51-510-8086

E-mail : sangyull@pusan.ac.kr

${ }^{\dagger}$ The authors are equally contributed. include MAGE, BAGE, and GAGE1 defined in T cell epitope cloning technique $[1,17,18]$ as well as SSX family, NY-ESO-1, SCP-1, NY-TLU-57, and NY-SAR-35 in SEREX method $[4,5,6]$. The important point concerning the therapeutic use of $\mathrm{CT}$ antigens is that vaccines targeting them will not affect germ cells because they lack expression of the MHC molecules that are necessary for the presentation of the respective antigenic peptides.

Analysis of the expression pattern of the CT genes revealed that some of them are also expressed in breast cancer $[8,12]$. A report about the composite expression of CT genes in primary breast cancer shows that these tumors frequently express a selected spectrum of CT genes, SCP-1 and SSX-4, specially [9]. However, little is known about analysis of a larger panel of $\mathrm{CT}$ genes in Eastern Asian primary breast cancer.

In the present study, we investigated a comprehensive analysis of a large panel of CT antigens, including NY-SAR35 and NY-TLU-57 identified recently as well as MAGE-3 and NY-ESO-1, in Korea breast tumors.

\section{Materials and Methods}

\section{Tissues}

Human tumor tissues were obtained from Department of 
Surgery and made a diagnosis and staging by Department of Pathology, Pusan National University Hospital. The tumor samples were obtained from 29 patients with breast cancer on the primary definitive operation. The tissues were frozen in liquid nitrogen and stored at $-80^{\circ} \mathrm{C}$ until use.

\section{Reverse transcription PCR (RT-PCR)}

Total RNA was prepared from tumor tissues using guanidinium thiocyanate. The cDNA preparations used as templates in the RT-PCR reactions were prepared by using 500 ng of total RNA in conjunction with the Superscript first strand synthesis kit (Invitrogen Life technologies, Carlsbad, CA, USA). The cDNA templates used were normalized on the basis of amplification of GAPDH (BD Bioscience Clontech, Palo Alto, CA, USA).

PCR primers and conditions were used for the analysis of previous reports $[5,6]$ and the CT gene database of the Academy of Cancer immunology (Table 1).

For PCR, $25 \mu \mathrm{l}$ reaction mixtures were utilized, consisting of $2 \mu \mathrm{l} \mathrm{cDNA}, 0.2 \mathrm{mM}$ dNTP, $1.5 \mathrm{mM} \mathrm{MgCl} 2,0.25 \mu \mathrm{M}$ gene-specific forward and reverse primers, and $2.5 \mathrm{U}$ Platinum $^{\circledR}$ Taq DNA polymerase (Invitrogen Life technologies, Carlsbad, CA, USA). Reaction mixtures were heated to $94^{\circ} \mathrm{C}$ for $2 \mathrm{~min}$, followed by 35 cycles of $94^{\circ} \mathrm{C}$ for 30 seconds, for 30 seconds at the respective annealing temperature as indicated above, and $72^{\circ} \mathrm{C}$ for $1 \mathrm{~min}$ (final cycle: $72^{\circ} \mathrm{C}$ for $5 \mathrm{~min}$ ) using a GeneAmp PCR System 9700 Thermal Cycler (Applied Biosystems, Foster City, CA, USA). Amplified products were analyzed on 1.5\% Agarose/ Tris-Acetate-EDTA gels stained with ethidium bromide.

\section{Immunohistochemistry}

Sections from paraffin-embedded blocks were dewaxed in xylene (three changes), rehydrated in a graded series of decreasing ethanol concentrations, and then rinsed in Tris-buffered saline $(50 \mathrm{mM}$ Tris/ $\mathrm{HCl}, \mathrm{pH} 7.4$, containing $100 \mathrm{mM}$ sodium chloride). The following primary antibodies for CT antigens were used: mouse monoclonal antibody

Table 1. PCR conditions and primers used to detect CT gene transcripts

\begin{tabular}{|c|c|c|c|}
\hline Gene & & Primer sequence & $\begin{array}{c}\text { Annealing } \\
\text { temperature }\left({ }^{\circ} \mathrm{C}\right)\end{array}$ \\
\hline NY-SAR-35 & $\begin{array}{l}\text { Forward } \\
\text { Reverse }\end{array}$ & $\begin{array}{l}\text { 5'-CTTGGTGCGATCAGCCTTAT-3' } \\
5^{\prime} \text {-TTGATGCATGAAAACAGAACTC-3' }\end{array}$ & 55 \\
\hline SCP-1 & $\begin{array}{l}\text { Forward } \\
\text { Reverse }\end{array}$ & $\begin{array}{l}\text { 5'-GTACAGCAGAAAGCAAGCAACTGAATG-3' } \\
5^{\prime} \text {-GAAGGAACTGCTTTAGAATCCAATTTCC-3' }\end{array}$ & 60 \\
\hline SSX-1 & $\begin{array}{l}\text { Forward } \\
\text { Reverse }\end{array}$ & $\begin{array}{l}5^{\prime} \text {-CTAAAGCATCAGAGAAGAGAAGC-3' } \\
5^{\prime} \text {-AGATCTCTTATTAATCTTCTCAGAAA-3' }\end{array}$ & 56 \\
\hline SSX-2 & $\begin{array}{l}\text { Forward } \\
\text { Reverse }\end{array}$ & $\begin{array}{l}5^{\prime} \text {-GTGCTCAAATACCAGAGAAGATC-3' } \\
5^{\prime} \text {-TTTTGGGTCCAGATCTCTCGTG-3' }\end{array}$ & 67 \\
\hline SSX-4 & $\begin{array}{l}\text { Forward } \\
\text { Reverse }\end{array}$ & $\begin{array}{l}\text { 5'-AAATCGTCTATGGTATATGAAGCT-3' } \\
\text { 5'-GGGTCGCTGATCTCTTCATAAAC-3' }^{\prime}\end{array}$ & 60 \\
\hline MAGE-1 & $\begin{array}{l}\text { Forward } \\
\text { Reverse }\end{array}$ & $\begin{array}{l}\text { 5'-GCTGGAACCCTCACTGGGTTGCC-3' } \\
\text { 5'-CGGCCGAAGGAACCTGACCCAG-3' }\end{array}$ & 62 \\
\hline MAGE-3 & $\begin{array}{l}\text { Forward } \\
\text { Reverse }\end{array}$ & $\begin{array}{l}\text { 5'-GAAGCCGGCCCAGGCTCG-3' } \\
\text { 5'-GGAGTCCTCATAGGATTGGCT-3' }^{\prime}\end{array}$ & 62 \\
\hline MAGE-4 & $\begin{array}{l}\text { Forward } \\
\text { Reverse }\end{array}$ & $\begin{array}{l}\text { 5'-GAGCAGACAGGCCAACCG-3' } \\
\text { 5'-AAGGACTCTGCGTCAGGC-3' }^{\prime}\end{array}$ & 65 \\
\hline MAGE-10 & $\begin{array}{l}\text { Forward } \\
\text { Reverse }\end{array}$ & $\begin{array}{l}\text { 5'-GGAACCCCTCTTTTCTACAGAC-3' } \\
5^{\prime} \text {-TCCTCTGGGGTGCTTGGTATTA-3' }\end{array}$ & 60 \\
\hline CT-7 & $\begin{array}{l}\text { Forward } \\
\text { Reverse }\end{array}$ & $\begin{array}{l}\text { 5'-GACGAGGATCGTCTCAGGTCAGC-3' } \\
5^{\prime} \text {-ACATCCTCACCCTCAGGAGGG-3' }\end{array}$ & 60 \\
\hline NY-TLU-57 & $\begin{array}{l}\text { Forward } \\
\text { Reverse }\end{array}$ & $\begin{array}{l}\text { 5'-TCATATGCCTAGCTCTGTCAAAAG-3' } \\
5^{\prime} \text {-TCCCGGGTCTGGCATCAATAAAAT-3' }\end{array}$ & 60 \\
\hline NY-ESO-1 & $\begin{array}{l}\text { Forward } \\
\text { Reverse }\end{array}$ & $\begin{array}{l}\text { 5'-CAGGGCTGAATGGATGCTGCAGA-3' } \\
5^{\prime} \text {-GCGCCTCTGCCCTGAGGGAGG-3' }\end{array}$ & 60 \\
\hline LAGE-1 & $\begin{array}{l}\text { Forward } \\
\text { Reverse }\end{array}$ & $\begin{array}{l}\text { 5'-CTGCGCAGGATGGAAGGTGCCCC-3' } \\
5^{\prime} \text { - GCGCCTCTGCCCTGAGGGAGC-3' }\end{array}$ & 62 \\
\hline
\end{tabular}


M3H67 (1: 2,000 diluted) to MAGE-A3/6 and mouse monoclonal antibody E978 (1:200) to NY-ESO-1. These antibodies were generous gifts from Drs. Old JA and JungBluth AA (Ludwig Institute for Cancer, NY, USA). Antigen retrieval procedure for enhanced detection of CT antigens involves immersion of tissue sections in TE (Tris-EDTA) buffer solution $\left(\mathrm{pH} \mathrm{9.0)}\right.$ and heating in a pressure cooker $\left(99^{\circ} \mathrm{C}\right)$ for $40 \mathrm{~min}$. After antigen retrieval, a cooling-off period of 30 min was followed. Endogenous peroxidase activity was inactivated with $5 \%$ hydrogen peroxide in methanol for $15 \mathrm{mi}-$ nutes at $37^{\circ} \mathrm{C}$. The two antibodies were incubated with the tissue sections one hour at $20^{\circ} \mathrm{C}$ in moisture chamber. After incubation with primary antibodies, immunohistochemical procedures were performed by ChemMate ${ }^{\mathrm{TM}}$ DAKO EnVision $^{\mathrm{TM}}$ Detection Kit (Peroxidase/DAB, Rabbit/Mouse). The reaction products were visualized by exposing sections to 3,3-diaminobenzidine (DAB).

\section{Results}

\section{Expression of CT genes and correlation with patient characteristics}

Tumor specimens were assessed for cDNA integrity and only those in which GAPDH could be amplified were investigated. Therefore, one of the 30 breast cancer cases had to be excluded from the analysis and 29 breast cancer specimens could be investigated for the expression of the following 13 CT genes; NY-SAR-35, SCP-1, SSX-2, SSX-4, MAGE-3, MAGE-4, MAGE-10, CT7, NY-TLU-57, NY-ESO-1, and LAGE-1. Intensities of PCR products were heterogeneous, and some specimens yielded only faint amplicon bands. These were scored positive only if the result could be reproduced by repeated RNA extraction and specific PCR from the same tumor specimen with clear bands. Expression of each CT gene was correlated with the following 4 parameters: age, size of primary tumor (T1/2 vs. T3/4), presence or absence of lymph node involvement (N0 vs. N1), histology. MAGE-1 and MAGE-3 with high frequency, as well NY-ESO-1 and others, was not associated with clinical characteristics. Even some results was adapted for a critical value, these correlations did not retain clinical significance (Table 2).

Expression of individual CT genes in primary breast carcinoma

As shown in Fig. 1, SCP-1 expression was undetectable
Table 2. Expression of CT antigens and correlation with patients characteristics

\begin{tabular}{|c|c|c|}
\hline Characteristic & $\begin{array}{l}\text { Number } \\
\text { of } \\
\text { patients }\end{array}$ & $\begin{array}{l}\text { Number of patients } \\
\text { with expression of } \\
\text { a CT gene mRNA }\end{array}$ \\
\hline Total & 29 & $28(97 \%)$ \\
\hline \multicolumn{3}{|l|}{ Age } \\
\hline$X \leq 45$ & 10 & $10(100 \%)$ \\
\hline $45<X$ & 19 & $18(94 \%)$ \\
\hline \multicolumn{3}{|l|}{ pT status } \\
\hline pT 1 & 6 & $6(100 \%)$ \\
\hline pT 2,3 & 23 & $22(96 \%)$ \\
\hline \multicolumn{3}{|l|}{$\mathrm{pN}$ status } \\
\hline $\mathrm{pN} 0$ & 20 & $20(100 \%)$ \\
\hline $\mathrm{pN} 1,2,3$ & 9 & $8(89 \%)$ \\
\hline \multicolumn{3}{|l|}{ Histological type } \\
\hline Invasive ductal carcinoma & 26 & $25(96 \%)$ \\
\hline other & 3 & $3(100 \%)$ \\
\hline
\end{tabular}

Others: Invasive apocrine carcinoma, Invasive lobular carcinoma, Mucinous carcinoma

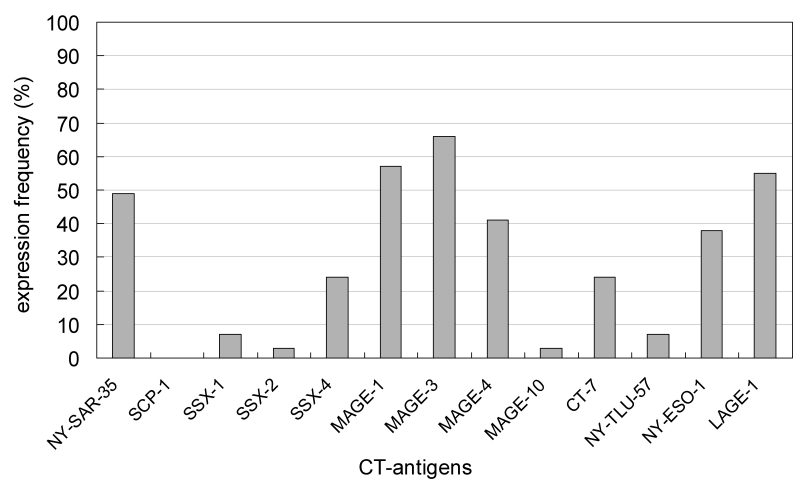

Fig. 1. Frequency of CT antigens expression in Korea Breast cancer tissues. The proportion of RT-PCR positive cases is shown as a percentage of 29 breast tumor samples.

in all 29 breast cancer specimens tested, SSX-2 and MAGE-10 was expressed in only one case, while SSX-1 and NY-TLU-57 expression was observed in two cases each. An intermediate frequency of expression was observed for LAGE-1 (59\%), NY-SAR-35 (49\%), MAGE-4 (41\%), NY-ESO-1 (38\%), CT-7 (24\%) and SSX-4 (24\%), which were expressed in 17, 16, 13, 11,7 , and 7 cases, respectively. The most frequently expressed CT genes in the breast cancer cases investigated in this study were MAGE-3 and MAGE-1, which were expressed in $19 / 29(66 \%)$ and $17 / 29(58 \%)$.

\footnotetext{
Simultaneous expression of CT genes in primary breast carcinoma

Of 29 primary breast tumors, only one did not express
} 
any the CT antigens tested. Expression of at least one antigen was observed in 28 breast cancer samples, and 25 cases expressed more than one CT gene. Three or more CT genes were expressed in 22 cases and one case co-expressed 9 antigens (Fig. 2).

Comparison of the mRNA and protein expression of NY-ESO-1 and MAGE-3

Representative examples of immunohistochemical results from one breast cancer specimen were shown in Fig. 3. For interpretation of staining, when the positive reaction (cytoplasmic, nuclear, or both) to the antibodies was found in more than $1 \%$ of tumor area, the tumor sample was considered positive. NY-ESO-1 and MAGE-3 proteins by immunohistochemistry were expressed in 11 of $29(38 \%)$ and 11 of $29(41 \%)$ breast tumors. Expressions of NY-ESO-1 and MAGE-3 proteins were found in 1/11 NY-ESO-1 RT-PCRpositive tumor samples $(10 \%)$ and in 6/19 MAGE-3 RT-PCR-

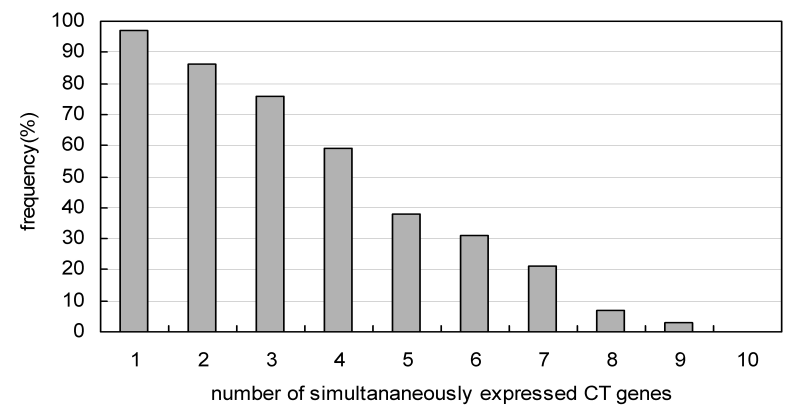

Fig. 2. Simultaneous expression of multiple CT antigens in Korea Breast cancer tissues. The proportion of breast tumor samples expressing at least one and up to $9 \mathrm{CT}$ antigens is shown as a percentage of 29 cases.

\section{NY-ESO-1}
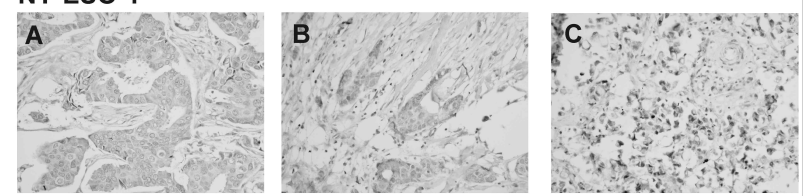

MAGE-3
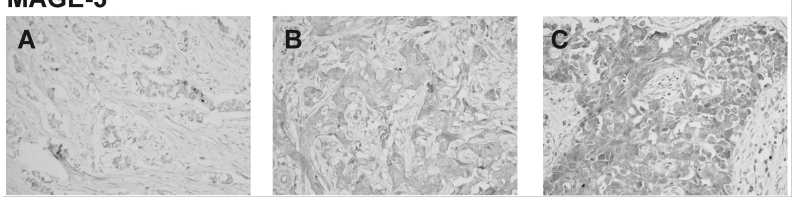

Fig. 3. Immunohistochemical staining of NY-ESO-1 by monoclonal antibody E978 (up) and MAGE-3 by monoclonal antibody $\mathrm{M} 3 \mathrm{H} 67$ (down) in an invasive ductal carcinoma of breast. In all cases antibody binding is indicated by brown staining (Magnification: $\times 400$ ). note: $\mathrm{A}$; weak staining, B ; moderate staining, $C$; strong staining.
Table 3. Expression of MAGE-3 and NY-ESO-1 proteins and comparison to RT-PCR

\begin{tabular}{|c|c|c|c|c|}
\hline \multirow{2}{*}{$\begin{array}{l}\text { Patiants } \\
\text { number }\end{array}$} & \multicolumn{2}{|c|}{ MAGE-3 } & \multicolumn{2}{|c|}{ NY-ESO-1 } \\
\hline & $\mathrm{IHC}$ & RT-PCR & $\mathrm{IHC}$ & RT-PCR \\
\hline 1 & - & + & + & - \\
\hline 2 & + & + & - & + \\
\hline 3 & + & - & - & + \\
\hline 4 & - & + & + & + \\
\hline 5 & - & + & - & + \\
\hline 6 & - & + & + & - \\
\hline 7 & + & + & - & + \\
\hline 8 & - & + & - & + \\
\hline 9 & + & - & - & + \\
\hline 10 & - & + & + & - \\
\hline 11 & + & - & + & - \\
\hline 12 & - & - & - & - \\
\hline 13 & - & + & - & + \\
\hline 14 & - & + & - & - \\
\hline 15 & + & - & + & - \\
\hline 16 & + & - & - & - \\
\hline 17 & - & + & - & + \\
\hline 18 & + & - & + & - \\
\hline 19 & - & - & + & - \\
\hline 20 & - & - & + & - \\
\hline 21 & + & + & - & - \\
\hline 22 & - & + & - & - \\
\hline 23 & + & + & - & - \\
\hline 24 & - & + & - & + \\
\hline 25 & - & + & - & - \\
\hline 26 & - & - & + & - \\
\hline 27 & + & + & + & - \\
\hline 28 & - & + & - & - \\
\hline \multirow[t]{2}{*}{29} & + & + & - & + \\
\hline & $12(41 \%)$ & $19(66 \%)$ & $11(38 \%)$ & $11(38 \%)$ \\
\hline
\end{tabular}

positive tumor samples (32\%), respectively (Table 3).

\section{Discussion}

To date, no a comprehensive analysis of CT genes expression in Korean (Asian) breast cancer patient has been published. In our study, the SEREX-defined genes (NY-ESO-1 and NY-SAR-35) and the CTL-defined genes (MAGE-3 and MAGE-1) were the most frequently expressed in Korean breast tumor samples. There is a high level of similarity between NY-ESO-1 and LAGE-1 (94\% nucleotide identity and $88 \%$ amino acid identity), including shared HLA-A2 binding $\mathrm{T}$ cell epitopes [11]. A widely expressed and the most immunogenic CT antigen known to date, NY-ESO-1/LAGE-1 are being investigated as targets for active cancer immunotherapy [2]. MAGE-3 is also being studied as a poten- 
tial cancer vaccine engineered to stimulate T-cell responses against tumors [7].

We investigated immunohistochemistry detection and mRNA expression of NY-ESO-1 and MAGE-3 in breast tumors (Table 3). Of the 29 tumors tested for immunohistochemical and RT-PCR analysis of NY-ESO-1, eleven cases were positive by RT-PCR and 1 of them was positive by staining with NY-ESO-1 monoclonal antibody. Among 18 samples that were negative by RT-PCR, 10 cases were positive by immunohistochemical analysis. An explanation for these results is heterogeneity in the distribution and expression level of NY-ESO-1 as suggested previously in other tumor types [19]. In analysis of MAGE-3 expression, MAGE-3 protein was found in 6/19 MAGE-3 RT-PCR-positive tumor samples and 5 cases were positive by immunochemical analysis in 10 MAGE-3 RT-PCR-negative tumor samples. The RT-PCR method cannot provide information about the expression level of tumor antigens in individual cells or the heterogeneous distribution of antigen expression in tissues. Therefore, it is needed to combine analysis by immunohistochemistry and RT-PCR to obtain information about expression level and distribution.

Of particular interest is NY-SAR-35, which represents a CT antigen as it appears to be a rare example of a cell surface antigen [6], were highly expressed in Korean breast cancer. Thus, the most frequent expression of this gene $\mathrm{s}$ in Korean breast cancer might be demonstrated to induce cellular and antibody responses in clinical vaccine trials.

From the data of our study (Fig. 2), it appears that 97\% of the patients with primary breast cancer would be eligible for specific immunotherapeutic approaches with at least one CT antigen in ways similar to those currently being evaluated in western breast carcinoma [9].

In conclusion, we demonstrate that Korean breast cancer frequently expresses CT antigens and highly percent more than one CT antigen, suggesting potential candidates for polyvalent immunotherapy.

\section{Acknowledgment}

This work was supported by Pusan National University Grant for two years (2007-2008).

\section{References}

1. Boel, P. C., M. L. Wildmann, R. Sensi, J. C. Brasseur, P.
Renauld, T. Boon, and B. P. van der. 1995. BAGE: a new gene encoding an antigen recognized on human melanomas by cytolytic T lymphocytes. Immunity 2, 167-175.

2. Chen, Q., H. Jackson, P. Parente, T. Luke, M. Rizkalla, T. Y. Tai, H. C. Zhu, N. A. Mifsud, N. Dimopoulos, K. A. Masterman, W. Hopkins, H. Goldie, E. Maraskovsky, S. Green, L. Miloradovic, J. McCluskey, L. J. Old, I. D. Davis, J. Cebon, and W. Chen. 2004. Immunodominant $\mathrm{CD} 4^{+}$responses identified in a patient vaccinated with full-length NY-ESO-1 formulated with ISCOMATRIX adjuvant. Proc. Natl Acad Sci. USA 101, 9363-9368.

3. Greenlee, R. T., T. Murray, S. Bolden, and P. A. Wingo. 2000. Cancer statistics. CA Cancer J. Clin. 50, 7-33.

4. Lee, S. Y. 2007. SEREX; discovery of tumor antigens. J. Life Science 17, 841-846.

5. Lee, S. Y. , B. Williamson, O. L. Caballero, Y. T. Chen, M. J. Scanlan, G. Ritter, C. V. Jongeneel, A. J. Simpson, and L. J. Old. 2004. Identification of the gonad-specific anion transporter SLCO6A1 as a cancer/testis (CT) antigen expressed in human lung cancer. Cancer Immun. 17, 4-13.

6. Lee, S. Y., Y. Obata, M. Yoshida, E. Stockert, B. Williamson, A. Jungbluth, Y. T. Chen, L. J. Old, and M. J. Scanlan. 2003. Immunomic analysis of human sarcoma. Proc. Natl. Acad Sci. USA 100, 2651-2656.

7. Marchandab, M., C.J.A. Puntc, S. Aamdald, B. Escudiere, W.H.J. Kruitf, U. Keilholzg, L. Håkanssonh, N. van Barenab, Y. Humbletb, P. Muldersc, M.-F. Avrile, A. M. M. Eggermontf, C. Scheibenbogeng, J. Uitersi, J. Wandersi, M. Delirej, T. Boona, and G. Stoterf. 2003. Immunisation of metastatic cancer patients with MAGE-3 protein combined with adjuvant SBAS-2: a clinical report. Eur. J. Cancer 39, 70-77.

8. Mashino, K. N., F. Sadanaga, H. Tanaka, H. Yamaguchi, H. Nagashima, I. K. Sugimachi, and M. Mori. 2001. Expression of multiple cancer-testis antigen genes in gastrointestinal and breast carcinomas. Br. J. Cancer 85, 713-720.

9. Mischo, A., B. Kubuschok, K. Ertan, K. D. Preuss, B. Romeike, E. Regitz, C. Schormann,D. Bruijn, A. Wadle, F. Neumann, W. Schmidt, C. Renner, and M. Pfreundschuh. 2006. Prospective study on the expression of cancer testis genes and antibody responses in 100 consecutive patients with primary breast cancer. Intl. J. Cancer 118, 696-703.

10. Rentzsch, C., S. Kayser, S. Stumm, I. Watermann, S. Walter, S. Stevanovic, D. Wallwiener, and B. Guckel. 2003. Evaluation of pre-existent immunity in patients with primary breast cancer: molecular and cellular assays to quantify antigen-specific $\mathrm{T}$ lymphocytes in peripheral blood mononuclear cells. Clin. Cancer Res. 9, 4376-4386.

11. Rimoldi, D., V. Rubio-Godoy, V. Dutoit, D. Lienard, S. Salvi, P. Guillaume, D. Speiser, E. Stockert, G. Spagnoli, C. Servis, J. C. Cerottini, F. Lejeune, P. Romero, and D. Valmori. 2000. Efficient simultaneous presentation of NY-ESO-1/LAGE-1 primary and nonprimary open reading frame-derived CTL epitopes in melanoma. J. Immunol. 165, 7253-7261.

12. Russo, V., C. Traversari, A. Verrecchia, M. Mottolese, P. G. Natali, and C. Bordignon. 1995. Expression of the MAGE 
gene family in primary and metastatic human breast cancer: implications for tumor antigen-specific immunotherapy. Int. J. Cancer 64, 216-221.

13. Scanlan, M. J., A. J. Simpson, and L. J. Old. 2004. The cancer/testis genes: review, standardization, and commentary. Cancer Immun. 4, 1.

14. Seregni, E., A. Coli, and N. Mazzucca. 2004. Circulating tumour markers in breast cancer. Eur. J. Nucl. Med Mol. Imaging 31 (Suppl 1), 15-22.

15. Simpson, A. J., O. L. Caballero, A. Jungbluth, Y. T. Chen, and L. J. Old. 2005. Cancer/testis antigens, gametogenesis and cancer. Nat. Rev. Cancer 5, 615-625.

16. Slamon, D. J., B. Leyland-Jones, S. Shak, H. Fuchs, V. Paton, A. Bajamonde, T. Fleming, W. Eiermann, J. Wolte , M., Pegram, J. Baselga, and L. Norton. 2001. Use of chemotherapy plus a monoclonal antibody against HER2 for metastatic breast cancer that overexpresses HER2. N. Engl. J.
Med 344, 783-792.

17. Van den Eynde, B., O. Peeters, O. De Backer, B. Gaugler, S. Lucas, and T. Boon. 1995. A new family of genes coding for an antigen recognized by autologous cytolytic T lymphocytes on a human melanoma. J. Exp. Med 182, 689-698.

18. van der Bruggen, P., C. Traversari, P. Chomez, C. Lurquin, E. De Plaen, E. B. Van den, A. Knuth, and T. Boon. 1991. A gene encoding an antigen recognized by cytolytic T lymphocytes on a human melanoma. Science 254, 1643-1647.

19. Vaughan, H. A., S. Svobodova, D. SMacgregor D, S. Sturrock, A. A. Jungbluth, J. Browning, I. D. Davis, P. Parente, Y. T. Chen, E. Stockert, F. St Clair, L. J. Old, and J. Cebon. 2004. Immunohistochemical and molecular analysis of human melanomas for expression of the human cancer-testis antigens NY-ESO-1 and LAGE-1. Clin. Cancer Res. 10, 8396-8404.

\section{초록 : 한국 유방암 환자에서 cancer/testis antigen의 발현분석}

배재호 · 김민주 · 박해림 · 송명하 · 김지연 - 이창훈 ${ }^{1}$ 곽희숙 ${ }^{2}$ 이상률*

(부산대학교 의학전문대학원 생화학교실, ${ }^{1}$ 병리학교실, ${ }^{2}$ 외과학교실)

Cancer/testis (CT) antigens은 여러 종류의 암에서는 발현이 되지만, 정상조직에서는 고환에서만 발현이 되는 특이성을 가지고 있다. 이러한 특이성은 immunotherapy을 하기 위한 항암백신 개발에 매력적인 유전자로 알려져 있다. 본 연구에서는 29개의 한국유방암조직에서 13개의 CT antigens (NY-SAR35, SCP-1, SSX-1, SSX-2, SSX-4, MAGE-1, MAGE-3, MAGE-4, MAGE-10, CT-7, NY-TLU57, NY-ESO-1 and LAGE-1)의 발현빈도를 RT-PCR을 통하 여 조사하고 환자의 임상학적 분류와 CT antigens의 발현빈도에 대하여 조사하였다. 29개의 유방암조직에 RT-PCR 결과, 13 개의 CT antigen중에 MAGE-3 (66\%)와 MAGE-1 (57\%)에서 발현빈도가 가장 높았고 LAGE-1 $(55 \%)$, NY-SAR-35 (49\%), MAGE-4 (41\%), NY-ESO-1 (38\%), CT-7 (24\%), SSX-4 (24\%) 순으로 발현빈도를 보였다. 그러나 SSX-1, SSX-2, MAGE-10와 NY-TLU-57의 발현은 3-7\%로 매우 낮았고 특히 SCP-1는 발현되지 않았다. 29 유방암 조직에서 적어도 하나 이상의 $\mathrm{CT}$ antigen이 발현되는 샘플은 $28(98 \%)$ 이였다. 그러나 환자의 임상학적 분류와 CT antigens의 발현빈도와는 특징적인 관계가 없음을 알 수 있었다. 29개의 유방암조직에서 MAGE-3와 NY-ESO-1 의 protein level에서의 발현을 알아보기 위하여 monoclonal antibody를 이용하여 면역조직염색을 하였다. MAGE-3 은 29개 조직 중에서 12 개의 조직에서 발현되었으며 NY-ESO-1은 11 개의 조직에서 발현되었다. 그러므로 CT antigens은 한국 유방암 조직에서 빈번하게 발현된 것을 알 수 있었으며 CT antigens을 기반으로 한 암 백신개발의 잠재적인 표적이 될 수 있을 것이라 사료된다. 